\title{
PERAN PSIKOLOGI MASSA BAGI PEMBIMBING IBADAH HAJI
}

\author{
Nazia Nuril Faudia \\ Balai Diklat Keagamaan Jakarta \\ Email: nazia.sabdho@gmail.com \\ Abstrak
}

Peran psikologi massa sangat penting dalam mengembangkan kompetensi pembimbing ibadah haji dan meningkatkan keprofesionalan sebagai pembimbing ibadah haji. Pada artikel ilmiah ini penulis merumuskan masalah, bagaimana pembimbing haji dapat meningkatkan kompetensinya di dalam melakukan kegiatan pembimbingan. Adapun tujuan penulisan ini untuk mendeskripsikan peran psikologi massa dalam meningkatkan keprofesionalitasan pembimbing ibadah haji yang berdampak pada keberhasilan pelaksanaan ibadah haji. Selanjutnya hasil analisis peran psikologi komunikasi massa juga mendeskripsikan pentingnya memahami psikologi massa jamaah haji dalam efektifitas komunikasi jamaah dengan pembimbingnya sehingga tujuan dari komunikasi yang dilakukan dapat tercapai dengan baik.

Kata Kunci: :Ibadah Haji, Psikologi Komunikasi Massa

\begin{abstract}
The role of psychology of mass communication is very important in developing the competence of Hajj supervisors and improving professionalism as a Hajj guide. In this scientific article the writer formulates a problem, how the Hajj supervisor can increase his competence in carrying out guidance activities. The purpose of this paper is to describe the role of mass psychology in increasing the professionalism of the Hajj pilgrimage guides which have an impact on the success of the implementation of the Hajj. Furthermore, the results of the analysis of the role of mass communication psychology also describe the importance of understanding the mass psychology of the pilgrims in the effectiveness of communication between the congregation and their supervisors so that the objectives of the communication can be achievedproperly.
\end{abstract}

Key: : the Hajj pilgrimage, psychology of mass communication.

\section{PENDAHULUAN}

\section{Latar Belakang,}

Pelayanan merupakan kegiatan yang ditawarkan oleh organisasi atau perorangan kepada konsumen yang bersifat tidak berwujud dan tidak dapat dimiliki. Oleh karena itu, perlu upaya peningkatan pelayanan kepada masyarakat. Dalam melayani jamaah haji pemerintah memberikan pelayanan dalam hal pelayanan umum, administrasi, ibadah, dan kesehatan, dan penyelenggaraan ibadah haji di Indonesia telah di selenggarakan jauh sebelum kemerdekaan Indonesia. Pada masa kolonial Belanda

Didalam pelayanan tersebut terdapat beberapa masalah diantaranya adalah rendahnya pengetahuan calon jamaah haji, sulitnya sebagian calon jamaah haji menggunakan bahasa Indonesia, serta banyaknya calon jamaah haji yang buta huruf. Sehingga dibutuhkan pembimbing calon jamaah haji yang kompeten yang dapat berkomunikasi dan menangkap kebutuhan para calon jamaah haji, sehingga ibadah haji dapat terlaksanakan dengan baik. Oleh karena itu, dibutuhkannya ilmu psikologi komunikasi massa bagi para pembimbing haji dalam memberikan pelayanan pembimbingan kepada para calon jamaah haji

Berdasarkan uraian di atas, maka penulis sangat tertarik untuk dapat meneliti tentang "penerapan psikologi komunikasi massa dalam pelayanan 
calon jamaah haji khususnya bagi para pembimbing jamaah haji".

\section{Perumusan Masalah}

Dari uraian di atas, maka rumusan masalah dalam penelitian ini adalah sebagai berikut: "Bagaimana peran psikologi komunikasi massa bagi pembimbing ibadah haji? "

\section{Tujuan}

Adapun tujuan dari penulisan ini adalah mendeskripsikan peran psikologi komunikasi masa bagi pembimbing ibadah haji.

\section{Manfaat Penelitian}

Adapun manfaat penelitian ini yaitu:

1. Sumbangan kajian ilmiah/referensi dalam psikologi komunikasi massa.

2. Memberikan pengetahuan dan keterampilan bagi pembimbing haji.

3. Memberi masukan kepada yang berkepentingan dalam menentukan kebijakan terkait peran psikologi massa bagi pembimbing ibadah haji.

\section{Kajian Teori}

Penelitian ini didukung oleh beberapa teori, diantaranya teori ibadah haji dan teori psikologi komunikasi massa.

Ibadah haji merupakan rukun Islam kelima yang wajib dilaksanakan oleh setiap orang Islam yang memenuhi syarat istitha'ah (kemampuan), baik secara finansial, fisik, maupun mental. Negara bertanggung jawab atas penyelenggaraan ibadah haji sebagaimana yang diamanatkan dalam Pasal 29 Ayat (2) Undang-Undang Dasar Negara Republik Indonesia Tahun 1945, yang menyatakan bahwa Negara menjamin kemerdekaan tiaptiap penduduk untuk memeluk agamanya masing-masing dan untuk beribadat menurut agama dan kepercayaannnya itu.

Indonesia sebagai salah satu negara yang memiliki jumlah penduduk beragama Islam terbesar di dunia, melakukan penyelenggaraan ibadah haji setiap tahunnya. Saat ini dasar dan payung hukum pelaksanaan penyelenggaraan ibadah haji berdasarkan pada Undang-undang Nomor 13 Tahun 2008 Tentang Penyelenggaraan Ibadah Haji. Isinya mengatur mengenai rangkaian kegiatan pengelolaan pelaksanaan ibadah haji yang meliputi pembinaan, pembimbingan, pelayanan, dan perlindungan jamaah haji.

Adapun tujuan penyelenggaraan ibadah haji yaitu untuk memberikan pembinaan, pembimbingan, pelayanan, dan perlindungan yang sebaik-baiknya bagi jamaah haji sehingga jamaah haji dapat menunaikan ibadahnya sesuai dengan ketentuan ajaran agama Islam.

Secara Bahasa, haji berasal bahasa Arab haj atau hijj, yang berarti menuju atau mengunjungi tempat yang agung. Dalam pengertian agama, haji adalah perjalanan menuju Mekkah untuk melaksanakan ibadah thawaf, sa ${ }^{\text {eci, }}$ wukuf di Arafah, dan seluruh rangkaian manasik ibadah haji sebagai bentuk pelaksanaan perintah Allah dan dalam kerangka mencari ridha-Nya.

Ibadah haji diwajibkan bagi setiap Muslim dan Muslimah yang mampu dalam sekali seumur hidup. Kewajiban untuk melaksanakan ibadah haji ditetapkan berdasarkan alQurean, Sunnah, dan Ijma"e. Dasar kewajiban haji dalam Al-Qureean adalah firman Allah yang artinya: "Sesungguhnya rumah yang mulamula dibangun untuk (tempat beribadat) manusia, ialah Baitullah yang di Bakkah (Mekkah) yang diberkahi dan menjadi petunjuk bagi semua manusia. padanya terdapat tanda-tanda yang nyata, (di antaranya) 
maqam Ibrahim; Barangsiapa memasukinya (Baitullah itu) menjadi amanlah dia; mengerjakan haji adalah kewajiban manusia terhadap Allah SWT, Yaitu (bagi) orang yang sanggup Mengadakan perjalanan ke Baitullah. Barangsiapa mengingkari (kewajiban haji), Maka Sesungguhnya Allah Maha Kaya (tidak memerlukan sesuatu) dari semesta alam.

Pengelolaan ibadah haji pada hakikatnya merupakan bentuk pelayanan yang diberikan kepada masyarakat. Dalam kaitan pengelolaan ibadah haji ada tiga bentuk pelayanan yang mesti diberikan, yakni pelayanan pembinaan manasik haji baik sebelum dan sesudah penyelenggaraan ibadah haji, pelayanan transportasi, pelayanan pemondokan, katering, dan kesehatan. Sehingga dapat disimpulkan bahwa hak jamaah haji adalah mendapatkan pelayanan ibadah haji yang maksimal salah satunya mendapatkan pembimbingan yang baik dan maksimal sehingga kegiatan ibadah haji dapat terlaksana dengan baik.

Pengertian Psikologi Komunikasi berasal dari perkataan Yunani "psyche" yang artinya jiwa, dan "logos" yang artinya ilmu pengetahuan, jadi Psikologi adalah ilmu pengetahuan tentang jiwa/ perilaku manusia. Sedangkan Komunikasi adalah suatu proses memberikan signal menurut aturan tertentu, sehingga dengan cara ini suatu sistem dapat didirikan, dipelihara, dan diubah. Sedangkan Massa menurut Gustave Le Bon adalah sekumpulan orang atau manusia yang berada dalam waktu dan tempat yang sama yang sama yang mempunyai ketertarikan yang sama yang bersifat sementara. Jadi dapat disimpulkan bahwa Psikologi Komunikasi Massa adalah adalah ilmu yang berusaha menguraikan, meramalkan dan mengendalikan peristiwa mental dan behavioral/ perilaku dalam komunikasi sekumpulan orang yang berada dalam waktu dan tempat yang sama untuk sementara dalam hal ini jamaah haji.

Psikologi mencoba menganalisis seluruh komponen yang terlibat dalam proses komunikasi. Pada diri komunikan, psikologi menganalisa karakteristik manusia komunikan serta faktor-faktor internal maupun eksternal yang mempengaruhi perilaku komunikasinya. Pada komunikator, psikologi melacak sifat-sifatnya dan bertanya: Apa yang menyebabkan satu sumber komunikasi berhasil dalam mempengaruhi orang lain, sementara sumber komunikasi yang lain tidak. Pada saat pesan sampai pada diri komunikator, psikologi melihat ke dalam proses penerimaan pesan, menganalisa faktor-faktor personal dan situasional yang mempengaruhinya, dan menjelaskann berbagai corak komunikan ketika sendirian atau dalam kelompok.

Jadi psikologi komunikasi adalah ilmu yang berusaha menguraikan, meramalkan dan mengendalikan peristiwa mental dan behavioral dalam komunikasi. Peristiwa mental adalah internal mediation of stimuli sebagai akibat berlangsungnya komunikasi. Sementara peristiwa behavioral adalah apa yang nampak ketika orang berkomunikasi.

Psikologi komunikasi berkaitan dengan bagaimana mencapai komunikasi yang efektif dalam interaksi manusia. Untuk itu maka memahami manusia memang menjadi kemutlakan jika kita ingin berhasil/efektif dalam berkomunikasi dengan manusia lain. 
Menurut Fisher dalam bukunya Jalaludin Rahmat pendekatan psikologi komunikasi memiliki ciri-ciri sebagai berikut:

1) Penerimaan Stimuli Secara Inderawi (Sensory Reception of Stimuly).

2) Proses yang Mengantarai Stimuli dan Respons (Internal Mediation Of Stimuli).

3) Prediksi Respons (Prediction of Response).

4) Peneguhan Response (Reinforcement of Response). Psikologi meneliti kesadaran dan pengalaman manusia. Hal tersebut diarahkan pada pusat perhatian perilaku manusia dan mencoba menyimpulkan proses kesadaran yang menyebabkan terjadinya perilaku manusia itu.

5) Psikologi pada perilaku individu komunikan, ketika akan melakukan komunikasi, tak bisa dipungkiri membutuhkan pihak lain sebagai pendengar atau komunikan untuk merespon pesan yang disampaikan.

Psikologi komunikasi juga melihat bagaimana respon yang terjadi pada masa lalu dapat meramalkan respon yang terjadi pada masa yang akan datang.

Konsep ini menunjukkan bahwa psikologi komunikasi sangat berperan dalam perubahan perilaku manusia, terutama saat manusia berkomunikasi dengan manusia lain, baik yang sifatnya interpersonal, kelompok, maupun massa. Ketika seseorang memahami dan mengerti psikologi komunikasi, saat komunikasi berlangsung antara komunikator dan komunikan, orang mampu melihat dan menganalisis gerak dan tingkah kedua komponen tersebut, yang berbicara dan yang mendengar. Dengan menganalisis pandangan ini, maka peran ilmu psikologi komunikasi dalam perkembangan masyarakat dan pengetahuan cukup besar.

Dalam kehidupan bermasyarakat adanya norma-norma atau aturanaturan tertentu yang mengatur perilaku manusia, dimana norma tersebut merupakan pedoman-pedoman atau batasan-batasan dalam gerak gerik atau perilaku manusia sebagai anggota masyarakat. Maka dengan adanya norma-norma tersebut, manusia sebagai anggota masyarakat baik tidak dapat berbuat seenaknya. Jadi berarti bahwa norma-norma itu berfungsi mengatur dorongan-dorongan untuk dapat menyesuaikan dengan norma-norma yang ada dalam masyarakat.

Atas dasar uraian tersebut di atas, maka dapat dikemukakan bahwa salah satu analisis mengenai perbuatan atau perilaku massa adalah berdasarkan faktor psikologis yang mendasarinya, yaitu orang bertindak dalam massa adalah berdasarkan atas dorongandorongan atau keinginan-keinginan dari dalam diri (internal) maupun dorongan dari luar (eksternal).

Dalam Undang-undang Nomor 13 Tahun 2008 tentang Penyelenggaraan Ibadah Haji pasal 3 mengamanatkan bahwa "Penyelenggaraan Ibadah Haji bertujuan untuk memberikan pembinaan, pelayanan, dan perlindungan yang sebaik-baiknya bagi Jamaah Haji sehingga Jamaah Haji dapat menunaikan ibadahnya sesuai dengan ketentuan ajaran agama Islam", sehingga hal ikhwal yang mendukung terwujudnya tujuan tersebut harus diupayakan semaksimal mungkin.

Seperti adanya petugas haji yang profesional dalam melayani jamaah, baik dari sisi manajerial maupun kemampuan membimbing ibadah 
harus ditingkatkan peran sertanya. Demikian juga telah ditetapkan dalam pasal 11 ayat 2, menyatakan bahwa: Dalam rangka Penyelenggaraan Ibadah Haji, Menteri menunjuk petugas yang menyertai Jamaah Haji, yang terdiri atas: 1)Tim Pemandu Haji Indonesia (TPHI), 2) Tim Pembimbing Ibadah Haji Indonesia (TPIHI), dan 3) Tim Kesehatan Haji Indonesia (TKHI).

Pembimbing ibadah haji yang profesional akan menghasilkan proses dan hasil pembimbingan yang bermutu dalam rangka mewujudkan jamaah haji mandiri yang berkualitas sehingga mampu menjawab kegamangan calon haji dalam melaksanakan ibadah. Kualitas tersebut antara lain diindikasikan dengan penguasaan pemahaman tentang perhajian, ketaqwaan, akhlak mulia, kesehatan, kecerdasan, kreativitas, dan kemandirian.

Menurut konsep Kementerian Agama Pembimbing adalah Alim Ulama' yang menguasai pengetahuan manasik haji atau mereka yang telah yang mengikuti Pelatihan Pelatih Calon Jamaah Haji yang diselenggarakan oleh Departemen Agama untuk memberikan bimbingan ibadah haji (Depag RI, 2001:2). Selanjutnya menurut Samsul Munir pembimbing ialah seorang yang menjadi rujukan dalam prilaku kehidupan sehari-harinya, seseorang yang memiliki kemampuan untuk melakukan bimbingan berdasarkan standar profesi (Munir, 2010:259). Pembimbing sama halnya da" $i$ yang

Dari beberapa definisi diatas, maka dapat disimpulkan bahwa pembimbing adalah orang-orang yang memilki kemampuan atau pengetahuan serta pengalaman yang dengan kemampuannya tersebut memberikan pemahaman ataupun pelatihan bimbingan manasik haji kepada calon jamaah dari segala usia yang membutuhkan pemaham terkait dengan ibadah haji yang akan dijalankan selama berada di Tanah Suci nanti.

Untuk menjadi seorang pembimbing bukanlah hal yang mudah, menjadi seorang pembimbing dituntut untuk memiliki persyaratanpersyaratan sebagai berikut (Arifin, 1949: 50- 51):

1) Memiliki pribadi yang baik dan menarik;

2) Memiliki dedikasi tinggi dalam bertugas;

3) Memiliki komitmen terhadap nilainilai kemanusiaan;

4) Memiliki kemampuan untuk mengadakan komunikasi baik;

5) Bersikap terbuka artinya tidak memiliki watak yang suka menyembunyikan sesuatu maksud yang tidak baik;

6) Memiliki ketenangan jiwa (kedewasaan) dalam segala perbuatan lahiriyah dan batiniyah;

7) Memiliki sikap mental suka belajar dalam ilmu pengetahuan yang berhubungan dengan tugasnya;

8) Bilamana pembimbing tersebut bertugas di bidang agama, berakhlak mulia, serta aktif menjalankan ajaran agamanya dan sebagainya;

9) Memiliki kemampuan kemasyarakatan (hubungan sosial). Pembimbing harus memiliki kemampuan melakukan hubungan kemanusiaan atau hubungan sosial, ukhuwah Islamiyah yang tinggi. Hubungan tersebut meliputi: orang yang dibimbing, teman sejawat dan orang lain selain yang di atas; 
10) Memiliki kemampuan komunikasi yang baik dan memiliki kemampuan menggerakan jamaah yang proaktif dan menyenangkan.

Sehingga dapat disimpulkan untuk menjadi pembimbing ibadah haji yang baik diperlukan ilmu psikologi komunikasi. Jika seorang pembimbing manasik haji ingin komunikasinya efektif dalam kegiatan manasik haji, maka langkah pertamanya ia harus dapat membuat calon jamaah haji itu faham apa yang disampaikannya, kemudian terjadi perubahan pendapat, sikap dan perilaku pada diri jamaah sesuai dengan yang diharapkan oleh pembimbing. Misalnya apabila pembimbing mampu mewujudkan pemahaman kepada jamaah bahwa disiplin itu baik, menjaga kesehatan itu perlu dan menghargai waktu itu amat penting, tetapi jamaah tetap tidak disiplin, tidak mau menjaga kesehatan dan tidak menghargai waktu, maka komunikasi itu pada hakekatnya belum dapat dikatakan efektif, sebab belum dapat merubah sikap dan perilaku jamaah sesuai dengan yang diinginkan oleh pembimbing jamaah.

Komunikasi efektif pembimbing haji merupakan salah satu pekerjaan yang dituntut untuk dapat melakukan komunikasi secara efektif dengan para calon jamaah haji. Karena tanpa komunikasi efektif, maka tujuan manasik haji tidak akan dapat tercapai, dan untuk mencapai komunikasi efektif salah satunya perlu penguasaan psikologi komunikasi. Sebab itu pembimbing manasik haji perlu menguasai psikologi komunikasi baik secara teoretis maupun secara praktis.

Secara psikologis, ada beberapa faktor yang dapat mempengaruhi agar komunikasi yang dilakukan pembimbing manasik dengan jamaah dapat berjalan dengan efektif, di antaranya dapat dikemukakan sebagai berikut:

1) Perlu adanya keterbukaan diri (self disclosure)

2) Memiliki perasaan empati

3) Pesan-pesan komunikasi yang disampaikan dapat difahami jamaah.

4) Pembimbing manasik haji harus mempunyai kredibilitas.

5) Pembimbing manasik haji dapat menjadi contoh tauladan yang baik Setiap kali berkomunikasi dengan orang lain, maka pembimbing haji sebaiknya melakukan hal-hal sebagai berikut:

1) Mengamati tingkah laku komunikan, apa yang ia katakan, bagaimana nada suaranya, sorot matanya, raut mukanya, gerak gerik tubuh dan tangannya, dsb;

2) Menafsirkan semua informasi yang diterima dari komunikan. Meliputi menafsirkan informasi itu sendiri apa adanya; menganalisa apa penyebab timbulnya kata-kata atau tingkah laku komunikan seperti itu; menanamkan prinsip pada diri sendiri bahwa tidak ada manusia yang sempurna;

3) Menunjukkan perasaan tertentu sebagai reaksi terhadap informasi yang diterima dari komunikan. Misalnya, menunjukkan rasa kasihan kepada komunikan, rasa prihatin dsb;

4) Menanggapi dengan hangat dan serius dengan jalan berniat untuk menolong atau menghibur perasaan komunikan.

Teknik komunikasi seperti ini juga efektif digunakan oleh pembimbing manasik haji, sebab dalam proses bimbingan, seorang pembimbing 
manasik haji juga harus menggunakan gaya bahasa yang mudah difahami oleh jamaah, sehingga terwujud kesamaan makna antara pembimbing dan yang dibimbing.

Di samping itu, pembimbing juga harus mempunyai kredibilitas, yaitu sifat kepercayaan dan keteladanan, motivasi positif dan ikhlas, hangat dan bersahabat, kharismatik, ahli di bidangnya, dinamis, proaktif dan empati.

Kemudian, pembimbing juga perlu menyampaikan materi bimbingan dengan tegas, lengkap, pesan-pesan verbal dan non-verbal sejalan, tidak terjadi perulangan kata atau kalimat secara berlebihan, mendorong munculnya umpan balik, menyesuaikan pesan-pesan dan gaya bahasa dengan kondisi jamaah, dan senantiasa mengamati sikap dan prilaku jamaah selama proses bimbingan berlangsung.

Dengan demikian jamaah diharapkan di samping dapat memahami materi bimbingan manasik

haji yang disampaikan, mereka juga mampu melaksanakannya dengan baik.

Berdasarkan uraian sebelumnya maka dapatlah disimpulkan bahwa

komunikasi efektif itu dapat terjadi apabila jamaah calon haji dapat memahami pesan-pesan yang disampaikan oleh pembimbing haji, kemudian dapat mempraktikkannya sesuai dengan yang diharapkan oleh pembimbing.

Dalam menyampaikan pesan, pembimbing haji dapat menggunakan lambang-lambang komunikasi baik yang bersifat verbal maupun yang bersifat non-verbal. Kemudian untuk mencapai komunikasi efektif itu, pembimbing haruslah bersifat terbuka, mempunyai empati yang tinggi, menggunakan lambang komunikasi yang mudah difahami, mempunyai kredibilitas dan dapat menjadi contoh tauladan yang baik bagi jamaahnya sehingga tujuan pembimbingan haji dapat tercapai dan terlaksanakannya ibadah haji dengan baik sesuai dengan kaidah yang benar.

Penelitian ini merupakan penelitian kualitatif sesuai dengan obyek kajian penelitian ini, maka jenis penelitian ini termasuk dalam kategori penelitian literature review yaitu dengan mencatat semua temuan mengenai psikologi komunikasi massa secara umum pada setiap pembahasan penelitian yang didapatkan dalam literatur-literatur dan sumber-sumber, dan atau penemuan terbaru mengenai psikologi komunikasi massa. Setelah mencatat, kedua, yaitu memadukan segala temuan, baik teori atau temuan baru terkait psikologi komunikasi massa.

\section{HASIL DAN PEMBAHASAN}

Diperoleh hasil kajian sebagai berikut: Peran (Role) seperti halnya status. Peran yang dijalankan seseorang juga bisa bermacam-macam. Sejumlah peran yang saling berhubungan dan melekat pada status tertentu disebut perangkat peran (Role set). Peran yang dijalankan seseorang merupakan kewajiban yang harus dilaksanakannya terkait dengan status yang dimilikinya. Dengan demikian, peran dapat diartikan sebagai perilaku yang diharapkan dari seseorang dengan status yang disandangnya dalam hal ini sebagai pembimbing ibadah haji.

Psikologi komunikasi berarti ilmu yang membahas tentang gejala-gejala kejiwaan manusia yang terlibat dalam 
proses komunikasi, baik kedudukannya sebagai komunikator maupun sebagai komunikan.

Secara selintas kita melihat bahwa komunikasi itu merupakan kegiatan yang cukup mudah dilakukan tanpa mengalami banyak kesulitan. Namun sering sekali orang yang menjadi sasaran komunikasi (komunikan) itu tidak dapat memahami apa yang dimaksudkan oleh komunikator (orang yang menyampaikan pesan). Dalam arti terjadi perbedaan pemahaman antara komunikator dan komunikan tentang suatu hal yang dibicarakan, atau komunikan dapat memahami pesanpesan yang disampaikan oleh komunikator, namun komunikan tidak

mau melaksanakan isi pesan sesuai dengan yang diharapkan komunikator.

Apabila terjadi keadaan seperti ini maka komunikasi itu dikatakan tidak efektif. Komunikasi dikatakan efektif apabila penerima (komunikan) menginterpretasikan pesan yang diterimanya sebagaimana yang dimaksudkan olehpengirim atau komunikator.

Terjadinya suatu kesamaan pemahaman antara komunikator dan komunikan tentang suatu hal yang dikomunikasikan, tidak menjamin kegiatan komunikasi itu sudah efektif, sebab kesamaan pemahaman hanyalah merupakan langkah awal untuk terujudnya komunikasi efektif. Komunikasi dikatakan efektif apabila komunikan disamping dapat memahami pesan yang disampaikan, juga harus mau melakukan apa yang diinginkan oleh komunikator.

Hal itu sesuai dengan tujuan asas komunikasi itu sendiri, yaitu terjadinya perubahan pendapat, sikap dan perilaku pada diri komunikan sesuai dengan yang diinginkan oleh komunikator.

Jika seorang pembimbing haji ingin komunikasinya efektif dalam kegiatan manasik haji, maka langkah pertamanya ia harus dapat membuat calon jamaah haji itu faham apa yang disampaikannya, kemudian terjadi perubahan pendapat, sikap dan perilaku pada diri jamaah sesuai dengan yang diharapkan oleh pembimbing. Misalnya apabila pembimbing mampu mewujudkan pemahaman kepada jamaah bahwa disiplin itu baik, menjaga kesehatan itu perlu dan menghargai waktu itu amat penting, tetapi jamaah tetap tidak disiplin, tidak mau menjaga kesehatan dan tidak menghargai waktu, maka komunikasi itu pada hakekatnya belum dapat dikatakan efektif, sebab belum dapat merubah sikap dan perilaku jamaah sesuai dengan yang diinginkan oleh pembimbing jamaah.

Komunikasi Efektif Pembimbing haji merupakan salah satu pekerjaan yang dituntut untuk dapat melakukan komunikasi secara efektif dengan para calon jamaah haji. Karena tanpa komunikasi efektif, maka tujuan manasik haji tidak akan dapat tercapai, dan untuk mencapai komunikasi efektif salah satunya perlu penguasaan psikologi komunikasi. Sebab itu pembimbing manasik haji perlu menguasai psikologi komunikasi baik secara teoretis maupun secara praktis.

Secara psikologis, ada beberapa faktor yang dapat mempengaruhi agar komunikasi yang dilakukan pembimbing manasik haji itu efektif, di antaranya dapat dikemukakan sebagai berikut:

1) Perlu adanya keterbukaan diri (self disclosure) 
2) Memiliki perasaan empati

3) Pesan-pesan komunikasi yang disampaikan dapat difahami jamaah.

4) Pembimbing manasik haji harus mempunyai kredibilitas.

5) Pembimbing manasik haji dapat menjadi contoh tauladan yang baik

Setiap kali berkomunikasi dengan orang lain, maka pembimbing haji sebaiknya melakukan hal-hal sebagai berikut:

1) Mengamati tingkah laku jemaah, apa yang ia katakan, bagaimana nada suaranya, sorot matanya, raut mukanya, gerak gerik tubuh dan tangannya. Dalam hal ini pembimbing harus megamati tingkah laku jemaah haji.

2) Menafsirkan semua informasi dari pembimbing yang diterima dari jemah haji. Meliputi menafsirkan informasi itu sendiri apa adanya; menganalisa apa penyebab timbulnya kata-kata atau tingkah laku jemaah haji seperti pemahaman menanamkan prinsip pada diri sendiri bahwa tidak ada manusia yang sempurna oleh pembimbing haji kepada jemaah haji.

3) Menunjukkan perasaan tertentu sebagai reaksi terhadap informasi yang diterima dari jemaah haji. Misalnya, pembimbing menunjukkan rasa kasihan kepada jemahan rasa prihatin

4) Pembimbing menanggapi dengan hangat dan serius dengan jalan berniat untuk menolong atau menghibur perasaan jemaah haji

Teknik komunikasi seperti ini efektif juga digunakan oleh pembimbing manasik haji, sebab dalam proses bimbingan, seorang pembimbing manasik haji juga harus menggunakan gaya bahasa yang mudah difahami oleh jamaah, sehingga terujud kesamaan makna antara pembimbing dan yang dibimbing. Di samping itu, pembimbing juga harus mempunyai kredibilitas, yaitu sifat kepercayaan dan keteladanan, motivasi positif dan ikhlas, hangat dan bersahabat, kharismatik, ahli di bidangnya, dinamis, proaktif dan empati.

Kemudian, pembimbing juga perlu menyampaikan materi bimbingan dengan tegas, lengkap, pesan-pesan verbal dan non-verbal sejalan, tidak terjadi perulangan kata atau kalimat secara berlebihan, mendorong munculnya umpan balik, menyesuaikan pesan-pesan dan gaya bahasa dengan kondisi jamaah, dan senantiasa mengamati sikap dan prilaku jamaah selama proses bimbingan berlangsung. Dengan demikian jamaah diharapkan di samping dapat memahami materi bimbingan manasik haji yang disampaikan, mereka juga mampu melaksanakannya dengan baik.

Berdasarkan uraian sebelumnya maka dapatlah disimpulkan bahwa komunikasi efektif itu dapat terjadi apabila jamaah calon haji dapat memahami pesan-pesan yang disampaikan oleh pembimbing haji, kemudian dapat mempraktikkannya sesuai dengan yang diharapkan oleh pembimbing.

Dalam menyampaikan pesan, pembimbing haji dapat menggunakan lambang-lambang komunikasi baik yang bersifat verbal maupun yang bersifat non-verbal. Kemudian untuk mencapai komunikasi efektif itu, pembimbing haruslah bersifat terbuka, mempunyai empati yang tinggi, menggunakan lambang komunikasi yang mudah difahami, mempunyai 
kredibilitas dan dapat menjadi contoh tauladan yang baik bagi jamaahnya sehingga tujuan pembimbingan haji dapat tercapai dan terlaksanakannya ibadah haji dengan baik sesuai dengan kaidah yang benar.

\section{KESIMPULAN}

Berdasarkan hasil penelitian dan pembahasan pada penelitian ini, maka dapat disimpulkan bahwa:

1. Pegelolaan ibadah haji sebagai bentuk sebuah pelayanan salah satunya melalui pembimbingan jamaah ibadah haji sehingga perlu dipahami urgensi atas tugas pembimbing haji dan bagaimana dapat meningkatkan kompetensi yang dibutuhkan oleh pembimbing ibadah haji khususnya dalam berkomunikasi dengan jamaah haji sehinggga pelaksanaan ibadah haji dapat terlaksana dengan baik.

2 Adanya peran besar psikologi komunikasi massa dalam efektifitas kegiatan bimbingan ibadah haji dimana jika petugas pembimbing ibadah haji memiliki kemampuan dan keterampilan dalam psikologi komunikasi massa maka ibadah haji dapat terlaksana dengan baik.

3. Komunikasi Efektif dalam pembimbing jamaah haji merupakan sebuah tuntutan agar dapat melakukan komunikasi dengan baik dan efektif dengan para calon jamaah haji.

4. Untuk mencapai komunikasi efektif salah satunya perlu penguasaan ilmu psikologi komunikasi. Sebab itu pembimbing manasik haji perlu menguasai psikologi komunikasi baik secara teoretis maupun secara praktis.

5. Secara psikologis, ada beberapa faktor yang dapat mempengaruhi agar komunikasi yang dilakukan pembimbing haji terhadap para jamaan itu efektif, di antaranya adalah: perlu adanya keterbukaan diri (self disclosure), memiliki perasaan empati, pesan-pesan komunikasi yang disampaikan dapat difahami jamaah, pembimbing haji harus mempunyai kredibilitas, dan pembimbing haji harus menjadi contoh tauladan yang baik bagi para jamaah, artinya seorang pembimbing haji harus memiliki integritas yang baik.

\section{DAFTAR PUSTAKA}

Adler, P.S. (1982). Beyond Cultural Identity: Reflection on Cultural and Multicultural Man'. Dalam L. Samovar \& R. Porter, ed. Intercultural Communication: A Reader. Ed. Ke-3. Belmon: Wadsworth.

Dedy Mulyana \& Jalaluddin Rakhmat. (1996). Komunikasi Lintas budaya, Panduan Berkomunikasi Dengan Orang-orang Berbeda Budaya. Bandung: PT. Remaja Rosdakarya.

Departemen Pendidikan Nasional Republik Indonesia. (2001). Kamus Besar Bahasa Indonesia, Edisi Ketiga. Jakarta: Balai Pustaka. 
Duffy, K.G. and Wong, F.Y. (2003). Community psychology. $3^{\text {rd }}$ Ed. Boston: Allyn and Bacon.

Gudykuns, W.B. \& Young Yun Kim. (1984). Communicating With Strangers: An Approach to Intercultural Communication. Reading: Addison-Wesley.

Hogg, M.A., \& Vaughn, G.M. (2002). Social Psychology. Harlow: Printice Hall.

Imam Syaukani. (1984). Manajemen Pelayanan Haji di Indonesia. Jakarta: Kementerian Agama RI Badan Litbang dan Diklat Puslitbang Kehidupan Keagamaan.

Jalaluddin Rakhmat. Psikologi Komunikasi. (1989) Bandung: Remadja Karya.

McQuail, D. (1987) Mass Communication Theoy An Introduction. London: Sage Publication.

Jonhson, D.W. (1981). Reaching Out, Interpersonal Effectiveness and Self-Actualization. Englewood Cliffs: Prentice-Hall.

Moskowitz, G.B. (2005). Social Cognition. New York: The Guilford Press.

Myers, D.G. (1999). Social Psychology. Boston: McGraw - Hill.

R.A., \& Byrne, D. (1997). Social Psychology. Boston: Allyn and Bacon.

Orford, J. (1992). Community psychology: Theory and practice. NY: John Wiley \& Sons Ltd.

Sarwono, S.W. (1996). Psikologi Sosial. Individu dan Teori-teori Psikologi Sosial. Jakarta: Balai Pustaka.

Walgito, Bimo. (2003). Psikologi Social Suatu Pengantar, Yogyakarta: Andi Yogyakarta.

Supratiknya, A. (1999). Komunikasi Antarpribadi Tinjauan Psikologis. Yogyakarta: Kanisius. 